Pathophysiology

of Haemostasis and Thrombosis
Pathophysiol Haemost Thromb 2005;34:164-168

DOI: $10.1159 / 000092417$

\title{
Scratching below the Surface: Wound Healing and Alanine Mutagenesis Provide Unique Insights into Interactions between Eristostatin, Platelets and Melanoma Cells
}

\author{
Mary Ann McLane Xiaoming Zhang Jing Tian Claire Zelinskas \\ Apoorva Srivastava Brett Hensley Carrie Paquette-Straub \\ Department of Medical Technology, University of Delaware, Newark, Del., USA
}

\author{
Key Words \\ Disintegrin · Integrin $\cdot$ Metastasis $\cdot$ Cancer $\cdot$ Melanoma . \\ Phosphorylation $\cdot$ Wound healing
}

\begin{abstract}
To study the molecular mechanism of the disintegrin eristostatin, cellular functional studies were performed using ten recombinant alanine mutants. ADP-induced platelet aggregation revealed critical contributions of seven residues within the 'RGD loop' (R24, R27, G28, N31) and C-terminus (W47, N48, G49) of this disintegrin. Using an in vitro scratch wound healing assay, four human melanoma cell lines yielded similar results when exposed to wildtype eristostatin. All eristostatin-treated cells healed less of the wounded area than control conditions. This phenomenon was reproduced when using fibronectin as the matrix. C8161 cells showed significant delay in wound closure with the $\mathrm{N}$-terminal mutant P4A but not with R24A or G28A. Evidence from our laboratory and others suggests neither alpha Ilb, alpha 4 nor alpha 5 integrins are directly involved in eristostatin's interactions. Eristostatin did not affect the number of melanoma cells in culture after $\mathbf{2 4} \mathrm{h}$ or the development of apoptosis. However,
\end{abstract}

phosphorylation studies performed after these melanoma cells were exposed to eristostatin revealed changes in several tyrosine phosphorylated molecules.

Copyright (C) 2005 S. Karger AG, Basel

\section{Introduction}

Cancer cells interact with their environment in order to replicate, gain nourishment, move and survive. Eristostatin is a monomeric disintegrin from the viper Eristicophis macmahoni. It has been shown to inhibit not only platelet aggregation [1] but in vivo lung/liver colonization by either murine or human melanoma cells [2-4]. Such inhibitory activity by other disintegrins has been attributed to interactions with $\alpha \operatorname{IIb} \beta 3$ (for platelet aggregation) and $\alpha v \beta 3, \alpha v \beta 5$ and/or $\alpha 5 \beta 1$ for glioma cell [5] and breast cancer [6] metastasis. The integrins $\alpha \operatorname{IIb} \beta 3, \alpha v \beta 3$ or $\alpha 5 \beta 1, \alpha 9 \beta 1$ and the $\beta 2$ subunit have been cited as disintegrin binding partners when analyzing intracellular signaling associated with cellular motility inhibition by disintegrins [7-13]. None of these would explain eristostatin's effect, because we and other investigators have shown that eristostatin interacts only minimally with

\section{KARGER}

(C) 2005 S. Karger AG, Basel

Fax +41613061234

E-Mail karger@karger.ch

www.karger.com
Accessible online at: www.karger.com/pht
Dr. Mary Ann McLane

Department of Medical Technology, University of Delaware

Willard Hall Education Building, room $305 \mathrm{G}$

Newark, DE 19716 (USA)

Tel. +1 302831 8737, Fax +1 302831 4180, E-Mail mclane@udel.edu 
$\alpha v \beta 3$ and not at all with $\alpha 5 \beta 1, \alpha v \beta 5$ or $\alpha 9 \beta 1$. The purpose of these studies was to determine whether eristostatin employs an integrin mechanism in its interactions with human melanoma cells, and whether structural motifs critical in its interactions with cancer cells and platelets differ.

\section{Materials and Methods}

\section{Chemicals and Media}

Standard laboratory chemicals and protease inhibitor were obtained from Sigma (St. Louis, Mo., USA). Dulbecco's modified Eagle's media (DMEM-F12) and phosphate-buffered saline (DPBS) were obtained from Mediatech (Herndon, Va., USA). Fetal bovine calf serum (FBS) was from GibcoBRL (Rockville, Md., USA). Antieristostatin antibodies were produced in rabbits as previously described [1]. Monoclonal anti-phosphotyrosine antibody (clone 4G10) was from Upstate Biotechnology (Charlottesville, Va., USA). Crude venom was obtained from Latoxan (Rosans, France). Antimouse IgG resin was from EBiosciences (San Diego, Calif., USA). Chemiluminescence assay kit was obtained from AP Biosciences (Piscataway, N.J., USA). Matrix-coated tissue culture plates (fibronectin, collagen I, collagen IV, laminin) were obtained from BD Biosciences (Mountainview, Calif., USA). Pronectin ${ }^{\circledR}$-F plates, using a non-animal source polymer that incorporates multiple copies of RGD interspaced between repeated structural peptide units, were a gift from Deni Galileo, University of Delaware.

\section{Cell Lines Used}

Human melanoma cell lines 1205LU, WM164 were kindly provided by Dr. Meenhard Herlyn (Wistar Institute, Philadelphia, Pa., USA), while C8161 and MV3 cells were obtained from Fred Meyskens (University of California, Irvine Cancer Center) and Goos N.P. van Muijen (University Medical Center Nijmegen, The Netherlands), respectively. M24met cells came from Ralph Reisfeld (The Scripps Institute, San Diego, Calif., USA). All cell lines were cultured in DMEM-F12 containing $L$-glutamine and supplemented with $10 \%$ FBS (DMEM-FF). Cells were grown at $37^{\circ} \mathrm{C}, 5 \%$ $\mathrm{CO}_{2}$, detached using $2 \mathrm{mmol} / \mathrm{l}$ EDTA and resuspended in DPBS.

\section{Preparation of Disintegrins}

Native eristostatin was isolated from crude venom of Eristicophis macmahoni by high-pressure liquid chromatography as previously described [1]. Wildtype eristostatin and ten mutations (Q1A, P4A, R24A, V25A, R27A, G28A, N31A, W47A, N48A, G49A) were expressed in $E$. coli using a modification of the method previously described [14]. Modifications included the use of a pET$39 \mathrm{~b}(+)$ expression plasmid and isolation of the 6-histidine fusion protein with a nickel resin.

\section{Platelet Aggregation Inhibition}

Aspirin-free blood was collected from healthy donors in $3.8 \%$ (w/v) sodium citrate (1:9 ratio), centrifuged at $1,300 \mathrm{~g}$ for $10 \mathrm{~min}$, with the platelet-rich plasma separated from the cells within $30 \mathrm{~min}$ of collection. The concentration of each recombinant or native disintegrin that inhibited platelet aggregation induced by $20 \mu M$ ADP was determined as described previously [15].
Wound Healing Assay

For serum-supplemented studies, melanoma cells (3E6) were plated in $35-\mathrm{mm}$ tissue culture plates and incubated overnight $\left(37^{\circ} \mathrm{C}, 5 \% \mathrm{CO}_{2}\right) \pm$ wildtype or mutant eristostatin $(3,000 \mathrm{nM})$ in DMEM-FF. The next day, three streaks were made in the middle of the monolayer using a sterile pipette tip, the cells were washed twice with DPBS, and the media was changed to fresh DMEM-FF \pm eristostatin or mutated protein $(3,000 \mathrm{nM})$. Measurements of the wound distance were taken using an ocular micrometer at each time point. Differences were calculated by comparing the zero time distance with the 12-hour distance for each condition, and expressed as a percent wound closure of the untreated control, which was taken to be $100 \%$. Statistical significance was evaluated using the Student's t test and considered significant at $p<0.05$, which is indicated in each figure and table by an asterisk. For studies using serum-free conditions, cells were starved overnight and then handled as before, in the presence of a specific matrix surface. A minimum of 9 observations for each cell type was made.

\section{Results and Discussion}

Eristostatin provides a unique tool with which to study integrin-ligand involvement in cancer cell physiology. Previous results suggest it is selective and potent for $\alpha \operatorname{IIb} \beta 3$ [16], and that it is capable of binding to the surface of at least 6 melanoma cell lines [2-4, 16, 17]. Using a set of chimeric mutations based on differences between eristostatin and echistatin, we have also shown that motifs within the 'RGD loop' and the C-terminus of eristostatin are most critical for its function [4]. Our current results using alanine mutants confirm these findings in platelets and melanoma cells. The $\mathrm{IC}_{50}$ values (mean \pm $\mathrm{SE})$ for Q1A $(135 \pm 20 \mathrm{nM})$ and P4A $(126 \pm 14 \mathrm{n} M)$ revealed inhibition of ADP-induced platelet aggregation with potency similar to that of wildtype eristostatin (113 $\pm 15 \mathrm{n} M) . \mathrm{R} 24 \mathrm{~A}(568 \pm 56 \mathrm{n} M), \mathrm{V} 25 \mathrm{~A}(172 \pm 29 \mathrm{n} M)$, N31A $(622 \pm 63 \mathrm{nM}), \mathrm{W} 47 \mathrm{~A}(229 \pm 41 \mathrm{n} M), \mathrm{N} 48 \mathrm{~A}(183$ $\pm 29 \mathrm{n} M)$ and G49A $(184 \pm 20 \mathrm{n} M)$ were $1.5-5$ times less potent, while R27A and G28A, from the RGD motif, showed no activity. This is in contrast to alanine mutagenesis results of Dennis et al. [18] in which critical residues for kistrin were only arginine $e^{49}$ and aspartic acid ${ }^{51}$ of its RGD motif. The same molecular mechanism is not likely relevant for eristostatin's effect on in vivo metastasis inhibition, since none of the melanoma cells used in these experiments express $\alpha \operatorname{IIb} \beta 3$ on their surface.

In order to establish the integrin dependence of the melanoma cell-eristostatin interaction, we performed scratch wound healing assays [19]. Initial studies on nonECM-coated tissue culture dishes showed a significantly decreased ability of all melanoma cells to close the wound 


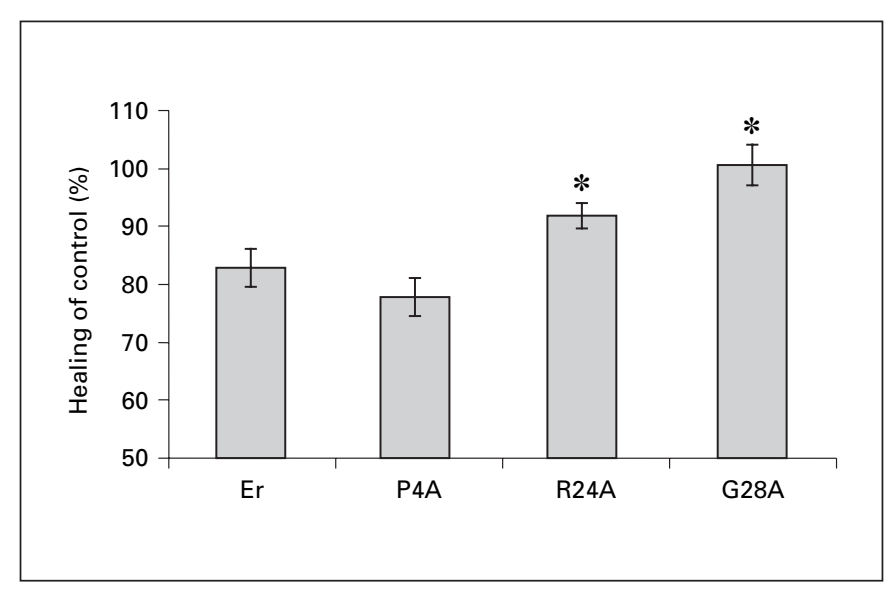

Fig. 1. Scratch-wounded C8161 monolayers, exposed to serum, treated with native or mutant eristostatin $(\mathrm{Er}) .{ }^{*} \mathrm{p}<0.05$.

in the presence of eristostatin (table 1). These results suggested that eristostatin must be present as the melanoma cells are proliferating and/or migrating to be effective. If eristostatin is present only before wounding, it is ineffective in preventing wound closure. Thus far, these tests have been repeated with eristostatin mutants using one cell line, C8161, which showed delay in wound closure with P4A but not with R24A or G28A (fig. 1). These results mirror the response found with platelet aggregation, and suggest that arginine and glycine at positions 24 and 28 , respectively, are critical for eristostatin's function while proline at position 4 is not. To remove cell proliferation as a variable in this assay, we repeated the experiments with serum-starved cells on specific matrix-coated tissue culture dishes. Significant differences were observed in wound closure of all melanoma cells on fibronectin matrix in the presence of eristostatin, but not when laminin or collagen types I or IV was used (fig. 2). The C8161 cell result pattern shown in figure 2 was observed with all cell lines used. We confirmed Morris' findings [2] that eristostatin did not affect the proliferation of melanoma cells in culture after $24 \mathrm{~h}$ or the development of apoptosis (data not shown). Figure 3 (left) shows that, while melanoma cells could form a monolayer on an RGD matrix, they began to form cell clusters within $1 \mathrm{~h}$ in the presence of eristostatin (right), confirming this disintegrin's interaction is RGD dependent. It was noted that untreated cells maintained contact with the RGD matrix for $12 \mathrm{~h}$, and gave identical wound closure results to those obtained when using a fibronectin matrix.

The receptor on melanoma cells with which eristostatin interacts is not yet known, but binding studies us-

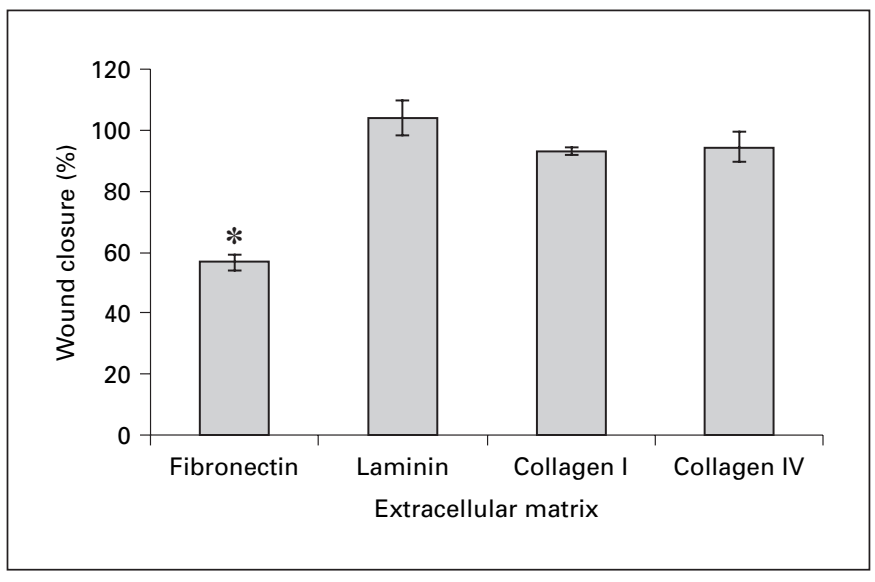

Fig. 2. Effect of eristostatin on wound closure of serum-starved melanoma monolayers on indicated matrices. $* \mathrm{p}<0.05$.

Table 1. In vitro wound closure in the presence of serum

\begin{tabular}{llll}
\hline $\begin{array}{l}\text { Melanoma } \\
\text { cell line }\end{array}$ & \multicolumn{3}{l}{ Percent closure } \\
\cline { 2 - 4 } & $+/-$ & $-/+$ & $+/+$ \\
\hline C8161 & $102 \pm 3.4$ & $83 \pm 3^{*}$ & $84 \pm 4^{*}$ \\
MV3 & $102 \pm 3.7$ & $72 \pm 6.5^{*}$ & $77 \pm 3^{*}$ \\
1205LU & $100 \pm 4$ & $56 \pm 5.6^{*}$ & $70 \pm 2.8^{*}$ \\
M24met & $99 \pm 4.3$ & $80 \pm 7.2^{*}$ & $87 \pm 5.5^{*}$ \\
\hline
\end{tabular}

Eristostatin was present before wounding $(+/-)$, after $(-/+)$, or at both times $(+/+)$. Data is mean \pm SE for at least 9 experiments.

$* \mathrm{p}<0.05$.

ing confocal microscopy [4] suggest a cell surface interaction, with an integrin being a likely target. The pattern of results for the wound healing and platelet aggregation assays is the same for wildtype eristostatin and mutations P4A, R24A and G28A. However, platelet aggregation utilizes $\alpha \operatorname{IIb} \beta 3$, while the wound healing assays are most likely utilizing integrins found on the surface of the melanoma cells, none of which express $\alpha \operatorname{IIb} \beta 3$. One other integrin proposed for involvement is $\alpha 4 \beta 1$ [20], based on studies performed with melanoma cell line MV3. However, eristostatin significantly inhibited C8161 lung colonization in vivo [16], and since C8161 cells do not express this integrin, a common mechanism using $\alpha 4 \beta 1$ is not possible. Fibronectin was the only matrix exhibiting a significant effect by eristostatin; therefore, we reviewed the twelve integrins which bind this matrix [21]. 

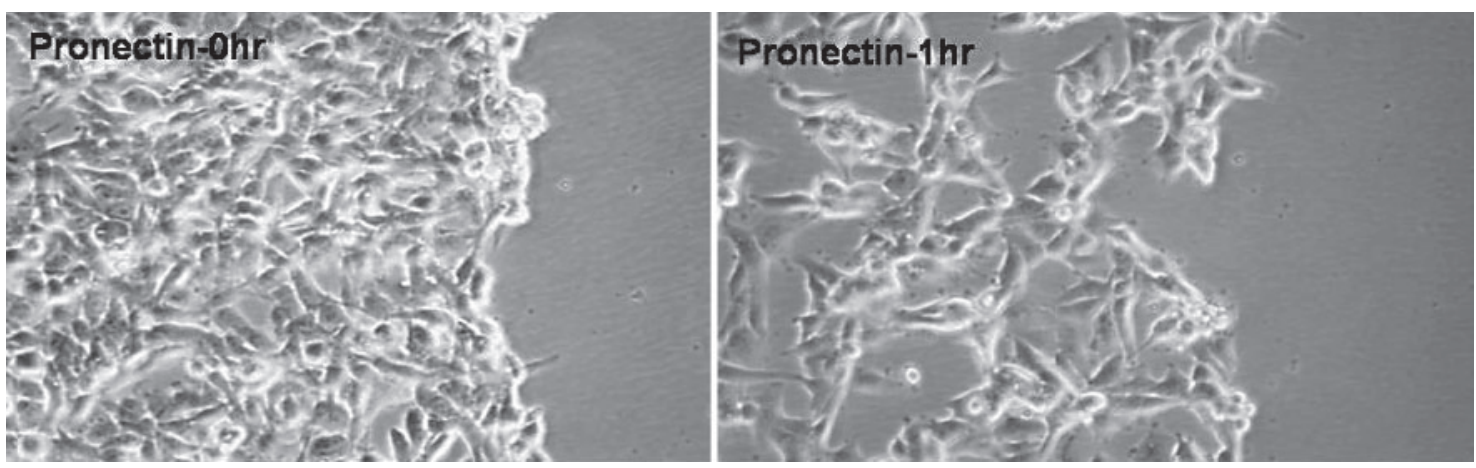

Fig. 3. Melanoma monolayers plus eristostatin plated on Pronectin ${ }^{\circledR}-\mathrm{F}$ without serum.

After eliminating those not RGD dependent, not involved in motility and those not found in common on our experimental melanoma cell lines, we are left with $\alpha 3 \beta 1, \alpha v \beta 1$ and $\alpha v \beta 6$ for additional studies. Preliminary evidence using crosslinked eristostatin suggests involvement of a protein with a mass of approximately $100 \mathrm{kDa}$, perhaps corresponding to the $\beta 1$ or $\beta 6$ subunit.

The wound healing assays suggest eristostatin affects the motility of the melanoma cells, and therefore may alter the intracellular signaling in these cells. Incubation of C8161, M24met and 1205LU melanoma cells with eristostatin caused an increase in tyrosine phosphorylation of a protein approximately $45 \mathrm{kDa}$ in each cell line.
M24met cells showed an additional band at $100 \mathrm{kDa}$, while $1205 \mathrm{LU}$ cells had bands at 60 and $120 \mathrm{kDa}$ proteins (manuscript in preparation). While the identity of these molecules is yet unknown, we expect these proteins are involved in motility and not proliferation or apoptosis since eristostatin affects neither process. Possible candidates include Crk, EGFR, FAK, FGFR, PDGFR, PTEN and Pyk2.

\section{Acknowledgements}

We are very grateful to Dr. Mary Beth Miele for her review of the manuscript. These studies were supported by the National Cancer Institute (CA98056-MAM).

\section{References}

1 McLane MA, Kowalska MA, Silver L, Shattil SJ, Niewiarowski S: Interaction of disintegrins with the alpha IIb beta 3 receptor on resting and activated human platelets. Biochem $\mathrm{J}$ 1994;301:429-436.

$\checkmark 2$ Morris VL, Schmidt EE, Koop S, MacDonald IC, Grattan M, Khokha R, McLane MA, Niewiarowski S, Chambers AF, Groom AC: Effects of the disintegrin eristostatin on individual steps of hematogenous metastasis. Exp Cell Res 1995;219:571-578.

-3 Danen EH, Marcinkiewicz C, Cornelissen IM, van K, Pachter JA, Ruiter DJ, Niewiarowski S, van $\mathrm{M}$ : The disintegrin eristostatin interferes with integrin alpha 4 beta 1 function and with experimental metastasis of human melanoma cells. Exp Cell Res 1998;238:188-196.

-4 McLane MA, Kuchar MA, Brando C, Santoli D, Paquette S, Miele ME: New insights on disintegrin-receptor interactions: eristostatin and melanoma cells. Haemostasis 2001;31:177182.
5 Schmitmeier S, Markland FS, Chen TC: Antiinvasive effect of contortrostatin, a snake venom disintegrin, and TNF-alpha on malignant glioma cells. Anticancer Res 2000;20:42274233.

-6 Zhou Q, Sherwin RP, Parrish C, Richters V, Groshen SG, Tsao-Wei D, Markland FS: Contortrostatin, a dimeric disintegrin from Agkistrodon contortrix contortrix, inhibits breast cancer progression. Breast Cancer Res Treat 2000;61:249-260.

7 Belisario MA, Tafuri S, Di-Domenico C, Della MR, Squillacioti C, Lucisano A, Staiano N: Immobilised echistatin promotes platelet adhesion and protein tyrosine phosphorylation. Biochim Biophys Acta 2000;1497:227-236.
8 Della MR, Squillacioti C, Garbi C, Derkinderen P, Belisario MA, Girault JA, Di-Natale $\mathrm{P}$, Nitsch L, Staiano N: Echistatin inhibits pp125FAK autophosphorylation, paxillin phosphorylation and pp125FAK-paxillin interaction in fibronectin-adherent melanoma cells. Eur J Biochem 2000;267:5047-5054.

$\checkmark 9$ Ritter MR, Zhou Q, Markland FS: Contortrostatin, a homodimeric disintegrin, actively disrupts focal adhesion and cytoskeletal structure and inhibits cell motility through a novel mechanism. Cell Commun Adhes 2001;8:7186.

10 Mercer B, Markland F, Minkin C: Contortrostatin, a homodimeric snake venom disintegrin, is a potent inhibitor of osteoclast attachment. J Bone Miner Res 1998;13:409-414.

-11 Nakamura I, Tanaka H, Rodan GA, Duong LT: Echistatin inhibits the migration of murine prefusion osteoclasts and the formation of multinucleated osteoclast-like cells. Endocrinology 1998;139:5182-5193. 
12 Coelho AL, de-Freitas MS, Oliveira CA, Moura NV, Zingali RB, Barja FC: Effects of jarastatin, a novel snake venom disintegrin, on neutrophil migration and actin cytoskeleton dynamics. Exp Cell Res 1999;251:379-387.

13 Coelho AL, De Freitas MS, Mariano-Oliveira A, Rapozo DC, Pinto LF, Niewiarowski S, Zingali RB, Marcinkiewicz C, Barja-Fidalgo C: RGD- and MLD-disintegrins, jarastatin and EC3, activate integrin-mediated signaling modulating the human neutrophils chemotaxis, apoptosis and IL-8 gene expression. Exp Cell Res 2004;292:371-384.

14 Wierzbicka-Patynowski I, Niewiarowski S Marcinkiewicz C, Calvete JJ, Marcinkiewicz MM, McLane MA: Structural requirements of echistatin for the recognition of alpha vbeta 3 and alpha 5beta 1 integrins. J Biol Chem 1999; 274:37809-37814.
15 Williams J, Rucinski B, Holt J, Niewiarowski S: Elegantin and albolabrin purified peptides from viper venoms: homologies with the RGDS domain of fibrinogen and von Willebrand factor. Biochim Biophys Acta 1990; 1039:81-89.

16 McLane MA, Sanchez EE, Wong A, PaquetteStraub C, Perez JC: Disintegrins. Curr Drug Targets Cardiovasc Haematol Disord 2004; 4: 327-355.

17 Beviglia L, Stewart GJ, Niewiarowski S: Effect of four disintegrins on the adhesive and metastatic properties of B16F10 melanoma cells in a murine model. Oncol Res 1995;7:7-20.
18 Dennis MS, Carter P, Lazarus RA: Binding interactions of kistrin with platelet glycoprotein IIb-IIIa: analysis by site-directed mutagenesis. Proteins 1993; 15:312-321.

19 Soderholm J, Heald R: Scratch n' screen for inhibitors of cell migration. Kagaku To Seibutsu 2005;12:263-265.

20 Danen EH, Marcinkiewicz C, Cornelissen IM, van KA, Pachter JA, Ruiter DJ, Niewiarowski S, Van MG: The disintegrin eristostatin interferes with integrin alpha 4 beta 1 function and with experimental metastasis of human melanoma cells. Exp Cell Res 1998;238:188-196.

21 Plow EF, Haas TA, Zhang L, Loftus J, Smith JW: Ligand binding to integrins. J Biol Chem 2000;275:21785-21788. 